\title{
Enterprise Risk Management between Network Capacity and Performance of Public Higher Education: A Proposed Framework
}

\author{
Ummu Ajirah Abdul Rauf, Juhaini Jabar, Nusaibah Mansor
}

\begin{abstract}
Most of the countries and organizations were implementing Enterprise Risk Management or known as ERM as it is already been introduced many years ago because it gives positive contributions towards the performance. It is also a way to help organizations manage the risks to achieving better results. About ten years ago, it has been implemented in Malaysia and being recommended to use it as a tool in an organization in order to recover the potential risks. ERM is regarded as an effective risk management technique and rapidly becomes the standard of best practice. Therefore, the variables that will affect the ERM implementation in an organization should be taken into account. Hence, this paper aim to propose a framework that will explains the relationship between network capacity and organization's performance. This relationship will be mediated by ERM implementation and this paper will be focusing on Malaysian Public Higher Education, which are 20 institutions that listed under the Ministry of Higher Education (MOHE).
\end{abstract}

Index Terms - Educational institution, enterprise risk management, knowledge management, network capacity.

\section{INTRODUCTION}

Higher education is one of the platforms for the people in order to explore new knowledge, to develop new ideas and to transform an innovation into business, industry and community. However, it is further stated that the development and implementation of a sustainable and practical corporate risk management such as ERM in order to tackle the risk that involved during that process is still far behind industry and business. In 2003, the risk management report in higher education was released by National Association of College and University Business Officers (NACUBO). This report gives an encouragement to the higher education in order for them to implement the practical risk management programs which is ERM [51].

Furthermore, it is stated that risks also arise in higher education and they should take risks into account as part of their strategic planning. Therefore, they have to discuss further about ERM so that they can gain deep understanding and must start to implement it in their institutions [6]. This is also been strongly recommended by the leading higher education associations in 2007, which are NACUBO and

Revised Manuscript Received on July 10, 2019.

Ummu Ajirah Abdul Rauf, Centre of Technopreneurship Development (CTeD), Faculty of Technology Management and Technopreneurship, Universiti Teknikal Malaysia, Melaka.

Juhaini Jabar, Centre of Technopreneurship Development (CTeD), Teknikal Malaysia, Melaka.

Nusaibah Mansor, Centre of Technopreneurship Development (CTeD), Faculty of Technology Management and Technopreneurship, Universiti Teknikal Malaysia, Melaka. Faculty of Technology Management and Technopreneurship, Universiti

University Risk Management and Insurance Association (URMIA). This is because ERM can help in dealing and managing with the key areas of risk which will lead to achievements of their objectives [19], [51]. It can thus reduce the risks, so that the specific organizational performance can be met [55].

However, in Netherlands, their higher education still does not have a policy of integrated risk management [19]. Meanwhile, during 2011, in order to gain an autonomy status, the organized risk management has to be implemented in public higher education in Malaysia. This is the terms and conditions that has been set up by the University Good Governance Index (UGGI). Therefore, in 2018, the last six of 20 public universities in Malaysia were finally granted autonomy status by the Ministry of Education. Before that, 14 public universities have already acquired their respective autonomous status [31]. However, this autonomous status will cause these universities to compete intensively in the higher education market, which will result the increasing of an exposure to multidimensional risks [33].

Multidimensional risks involve uncertainty of government funding, growth of postgraduate students and severe competition for quality of international student [33]. This poses a major threat for universities to examine a practical framework for risk management and also performance of organization. However, there is still little literature about the practices of risk management that related to higher education although there is an abundance of literature on risk management [51].

Nevertheless, risk management has been established during the late 1940s and early 1950s as a part of process of decision-making. During that time, risk management was practiced in a traditional way which the risks were being handled individually and not having the connection towards each of risks. Meanwhile, ERM is concerning on maximizing the risk-taking process [25].

Hence, nowadays, most of the organizations were applying the concept of ERM in order to tackling with risks effectively and efficiently [16], [23], [47], [48]. ERM is an approach of identifying, assessing and prioritizing the risk in order to manage the uncertainties that exist in an organization. As a result, both academics and practitioners

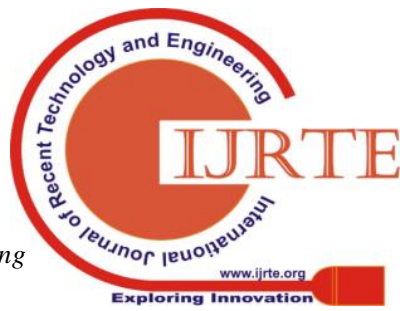




\section{ENTERPRISE RISK MANAGEMENT BETWEEN NETWORK CAPACITY AND PERFORMANCE OF PUBLIC HIGHER EDUCATION: A PROPOSED FRAMEWORK}

show a significant interest towards the performance measurement of an organization [48].

Thus, most of organizations would ensure that the measurement of performance must be done comprehensively and systematically [39]. This is because, their aim is to improve the performance so that they can attract the investor and their relationship with the stakeholders will be maintained. This can be supported by previous study, which stated that in order to attract the investors and to increase the market share, it is vital for an organization to have a well performance and good record of business performance [34]. However, nowadays, risks have become the key factor in all strategic planning and decisions of the business. Therefore, risk management has received significant interest by many organizations and stakeholders [21].

Besides, the argument in which performance of organizations will improve by using the ERM has gained significant support [18]. This paper will be supported in the knowledge management components which will enable an organization to improve performance by implementing ERM [15], [24], [35]. In addition, there was very little study that has conducted on ERM implementation particularly in Malaysian public higher education.

Therefore, in order to fill the gap, this paper aims to propose a framework that will enhance the understanding towards ERM implementation by investigating the extent of ERM implementation among Malaysian Public Higher Education. This paper will be focusing on the network capacity that extracted from Knowledge Management components by [15]. Hence, the objectives of this paper are:

1) To examine the extent of ERM implementation among public higher education.

2) To establish the relationship between network capacity and public higher education's performance.

3) To investigate the effect of mediating of ERM implementation on network capacity and public higher education's performance.

\section{LITERATURE REVIEW}

\section{A. Definition Enterprise Risk Management}

Even though, there are various definitions of ERM from [9], [13], [22]. However, it is usually defined by COSO (Committee of Sponsoring Organizations of the Treadway Commission) in 2004:

"A process which involving the board of directors, management and other personnel. It is applied in strategy setting and across the enterprise in order to identify unfavourable events that may affect the organization, manage risk to be within its risk appetite, and to provide reasonable solution which in line with the organization's objectives".

There are three important attributes based on the various definitions of ERM, which are ERM must handle all business units, ERM must include all types of risk, and ERM must in

Enterprise Risk Management (ERM) is an approach which is different from the silo or traditional approach. It is a holistic approach in order to identify the potential risks that encountered by an organization and also to select line with the organization's objectives and strategy [1].

appropriate responses that match the risk appetite of the organizations [18].

\section{B. Network Capacity and Organizational Performance}

Network capacity is defines as the highest number of users that the network can support while maintaining the quality of the network services of each user [50].

Various studies indicate that organizations can attain the valuable resources and improve their performance through networks [10], [17], [27], [42], [43]. This is because it was further stated that networks are one of the platforms to identify opportunities that the organization can easily achieve [46]. Meanwhile, the connection between network and organizational performance has been investigated by [7], [20], [32]. Moreover, the business partners or investors will see organization with valuable resources as an opportunity for them, which in turn improve the performance of organizations [8].

Nevertheless, networking and network management is important and helpful in addressing ambitious, complex, multi-resource policies or organizational demands [37], [40]. This can be supported by [40], who stated that network activity allows organizations to reduce transaction costs and gain resources and power. In addition, networks also promote group learning and building strategy [2]. Previous researchers have consistently shown that networking issues are positively affecting the performance outcomes [3], [29], [30], [38]. Therefore, this study proposing the following hypothesis:

H1: There is a positive relationship between network capacity and performance of public higher education.

\section{Network Capacity and Enterprise Risk Management}

There are three elements to create knowledge relevant to ERM within an organization which are transferring the knowledge (tacit to explicit) and vice versa [36]; understanding the production of the knowledge [11], [53] and organizing the risk knowledge [54]. All of these elements are related to the ability of the network to connect people for mobilization of knowledge.

Furthermore, network support for web portals can be a good platform for sharing risk knowledge, as sometimes there are language difficulties associated with risk within organizations. Hence, networking in organizations can enable the expertise to solve various problems that arise in organizations [13], [44], [52]. It is further stated that network support for web portals is one of the platforms that are vital to risk management and enable users to use the search process effectively because they may not be able to search effectively at times whenever there is a lot of available knowledge, such as risk management [4], [45].

In addition, consolidating and integrating internal information, reporting, risk reduction data in organizations [28], [44], and enhancing web services [5] can also contribute to a better sharing of risk knowledge. In order to respond to risk threats, an information management is needed [49].

Besides, network capacity to connect people within the organization could be an advantage in implementing ERM

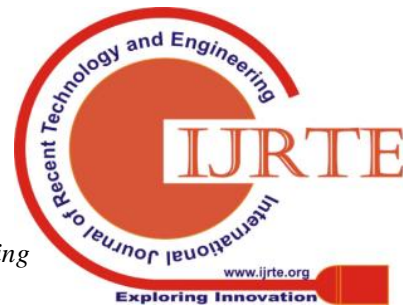


[14]. Therefore, this study proposing the following hypothesis:

$\mathrm{H} 2$ : There is a mediating effect of implementation of ERM on network capacity and performance of public higher education.

\section{A PROPOSED FRAMEWORK}

This paper will investigate the extent of implementation of ERM among Malaysian Public Higher Education.

Based on the literature, there are eight components identified under Knowledge Management by [15], [41] that contribute to the extent of implementation of ERM in organization. These eight components include the network capacity. Hence, this paper will analyze the relationship between network capacity and performance of organization and also the effect of mediating of Enterprise Risk Management on this relationship.

The proposed framework for the research is shown in Fig. 1.

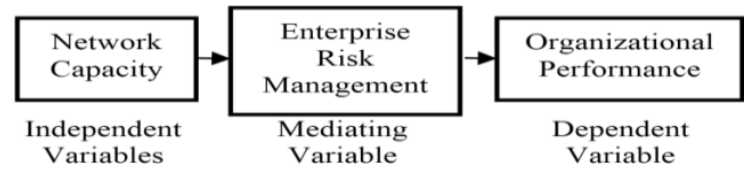

Fig. 1. Conceptual framework

\section{METHODOLOGY \& RESULTS}

\section{A. Sample and Data Collection Method}

The target population for this study is Malaysian public higher education. The unit of analysis will be a list of all 20 of Malaysian public higher education. $(n=20)$ which listed under Ministry of Higher Education [31]. The questionnaire will be adapted from previous studies which used a fivepoints Likert scale, therefore in order to be consistent and to make a comparison of the findings, this study also will be used a five-points Likert scale. The questionnaire then will be distributed to top manager, risk manager and internal audit since they are the person that responsible for enterprise risk management implementation in organizations.

\section{B. Instrument of Study}

Instrument that will be used in this study is structured questionnaires. The questionnaire of this study will be adapted from the previous studies as shown in Table 1.

Table 1: Development measures of variables

\begin{tabular}{|c|c|c|}
\hline Variables & Sources & Likert Scale \\
\hline Network Capacity & {$[41]$} & 5-points \\
\hline $\begin{array}{c}\text { Enterprise Risk } \\
\text { Management }\end{array}$ & {$[26]$} & 5-points \\
\hline $\begin{array}{c}\text { Organizational } \\
\text { Performance }\end{array}$ & {$[33]$} & 5-points \\
\hline
\end{tabular}

\section{CONCLUSION}

In conclusion, the aim of this paper is to propose a framework which will explain the effect of mediating of ERM implementation on network capacity in Malaysian public higher education. This paper suggested one of the components under Knowledge Management which are network capacity which will influences the extent of ERM implementation and organizations' performance. Under the proposed framework, two hypotheses have been developed and have to be empirically tested. The purpose of this paper is to add value to the knowledge that is limited in the area of ERM. This paper will also give relevant government agencies an insight into formulating new policies or strategies on issues related to ERM in Malaysia.

\section{ACKNOWLEDGMENT}

The authors would like to thank Universiti Teknikal Malaysia Melaka for the UTeM Zamalah Scheme for sponsorship.

\section{REFERENCES}

1. C. Abrams, J. V. Kanel, S. Muller, B. Pfitzmann, and S. R. Taylor, "Optimized enterprise risk management," IBM Systems Journal, 46(2), 2007, pp. 219-234.

2. R. Agranoff, Managing Within Networks: Adding Value to Public Organizations. Washington DC: Georgetown University Press, 2007.

3. R. Agranoff, and M. McGuire, Collaborative Public Management: New Strategies for Local Governments. Washington DC: Georgetown University Press, 2003.

4. M. Alavi, and D. Leidner, "Review: Knowledge management and knowledge management systems: Conceptual foundations and research issues," MIS Quarterly, 25(1), 2001, pp. 107136.

5. D. Anderson, H. H. Barber, J. Hill, J. Nasir, J. Javed, J. Lawler, and Z. Li, "A study of Web services projects in the financial services industry," Information Systems Management, 22(1), 2005, pp. 66-76.

6. Association of Governing Boards of Universities and Colleges and United Educators (AGB), The state of enterprise risk management at colleges and universities today. Available: http://www.vsu.edu/files/docs/internalaudit/the-state-of-enterprise-risk-manangement-at-collegesand-universities-today.pdf.

7. K. M. K. Bengesi, and I. L. Roux, "The influence of dimensions of networking capability in small and medium enterprise performance," International Journal of Business and Social Science, 5(2), 2014, pp. 189-200.

8. J. M. Bonner, D. Kim, and S. T. Cavusgil, "Self-perceived strategic network identity and its effects on market performance in alliance relationships," Journal of Business Research, 58(10), 2005, pp. 1371-1380.

9. Casualty Actuarial Society, Overview of enterprise risk management. Available: https://www.casact.org/area/erm/overview.pdf.

10. H. Chen, and T. J. Chen, "Network linkages and location choice in foreign direct investment," Journal of International Business Studies, 29(3), 1998, pp. 445-467.

11. C. Choo, The Knowing Organisation.New York: Oxford University Press, 1998.

12. Committee of Sponsoring Organizations of the Treadway Commission (COSO), Enterprise risk management-integrated framework: Executive summary and framework. New York: American Institute of Certified Public Accountants, 2004.

13. G. Dickinson, "Enterprise risk management: Its origin and conceptual foundation," Geneva Papers on Risk and Insurance, 26(3), 2001, pp. 360-366.

14. M. Earl, "Regarding the knowledge as a process and KM," Journal of Management Information Systems, 18(1), 2001, pp. 215-233. 

HIGHER EDUCATION: A PROPOSED FRAMEWORK

15. J. S. Edwards, "Business processes and knowledge management," in Encyclopedia of Information Science and Technology, M. Khosrow-Pour, Ed. Pennsylvania: IGI Global, 2009, pp. 471-476.

16. F. Afrinaldi, M. Z. M. Saman, and A. M. Shaharoun, "A decision making software for end-of-life vehicle disassemblability and recyclability analysis," IEEE international conference on industrial engineering and engineering management, 2009, pp. 2261-2265.

17. L. Gao, The internationalization of Chinese firms, determinants and the influence of dynamic capabilities and institutions on the post-internationalization performance. $\mathrm{PhD}$ thesis, England: Loughborough University, 2011.

18. L. A. Gordon, M. P. Loeb, and C. Y. Tseng, "Enterprise risk management and firm performance: A contingency perspective," Journal of Accounting and Public Policy, 28(4), 2009, pp. 301-327.

19. I. Helsloot, and W. Jong, "Risk management in higher education and research in the Netherlands," Journal of Contingencies and Crisis Management, 14(3), 2006, pp. 142159.

20. B. Kenny, A network perspective on international business: Evidence from SMEs in the telecommunications sector in Ireland. PhD thesis, Ireland: University of Limerick, 2009.

21. E. K. Kirimi, Organizational Behaviour: Structure, Principle and Practice. Nairobi: Aura Publishers, 2013.

22. F. W. Lai, and A. S. Fazilah, "Enterprise risk management framework and the empirical determinants of its implementation," International Conference on Business and Economics Research, 2011, pp. 1-5.

23. J. Lam, "Managing risk across the enterprise: Challenges and benefits," in Risk Management: A Modern Perspective, M. K. Ong, Ed. Massachusetts: Academic Press, 2006, pp. 3-19.

24. J. Lam, Enterprise Risk Management-From Incentives to Control. New Jwersey: John Wiley and Sons, 2003.

25. J. Lam, "Enterprise risk management and the role of the chief risk officer," E-Risk, 2000, pp. 1-5.

26. A. E. Lundquist, Enterprise Risk Management (ERM) at U.S. colleges and universities: Administration processes regarding the adoption, implementation, and integration of ERM. PhD thesis, Kalamazoo: Western Michigan University, 2015.

27. R. Madhavan, and A. Iriyama, "Understanding global flows of venture capital: Human networks as the "carrier wave" of globalization," Journal of International Business Studies, 40(8), 2009, pp. 1241-1259.

28. C. Marshall, L. Prusak, and D. Shpilberg, "Financial risk and need for superior knowledge management," California Management Review, 38(3), 1996, pp. 77-101.

29. K. J. Meier, and L. J. O'Toole, "Public management and educational performance: The impact of managerial networking," Public Administration Review, 6, 2003, pp. 689699.

30. K. J. Meier, and L. J. O'Toole, "Managerial strategies and behavior in networks: A model with evidence from U.S. public education," Journal of Public Administration Research and Theory, 3, 2001, pp. 271-293.

31. Ministry of Higher Education (MOHE), Directory of public universities. Available: http://jpt.mohe.gov.my/index.php/ipta/institusi-pendidikantinggi-awam/direktori-universiti-awam.

32. M. Mitrega, C. Ramos, S. Forkmann, and S. Henneberg, "Networking capability, networking outcomes, and company performance: A nomological model including moderation effects," IMP Conference, 2011, pp. 1-26.

33. M. A. Mohd Shoki, Z. Norhayati, M. T. Muhammad Naquib, A. Azira, I. Nawawi, and I. Khalid, "A framework for risk management practices and organizational performance in higher education," Review of Integrative Business and Economics Research, 3(2), 2014, pp. 422-432.

34. A. Neely, "The challenges of performance measurement," Management Decision, 42(8), 2004, pp. 1017-1023.
35. W. B. Nocco, and M. R. Stulz, "Enterprise risk management: Theory and practice," Journal of Applied Corporate Finance, 18(4), 2006, pp. 8-20.

36. I. Nonaka, and H. Takeuchi, The Knowledge-Creating Company: How Japanese Companies Creates the Dynamics of Innovation. New York: Oxford University Press, 1995.

37. L. J. O'Toole, "Treating networks seriously: Practical and research-based agendas in public administration," Public Administration Review, 1, 1997, pp. 45-52.

38. L. J. O'Toole, and K. J. Meier, "Public management in intergovernmental networks: Matching structural networks and managerial networks," Journal of Public Administration Research and Theory, 4, 2004, pp. 469-494.

39. C. Parker, "Performance measurement," MCB University Press, 49(2), 2000, pp. 63-66.

40. K. G. Provan, and H. B. Milward, "A preliminary theory of interorganizational network effectiveness: A comparative study of four community mental health systems," Administrative Science Quarterly, 40, 1995, pp. 1-33.

41. E. Rodriguez, and J. S. Edwards, "knowledge management in support of enterprise risk management," International Journal of Knowledge Management, 10(2), 2014, pp. 43-61.

42. D. Sharma, and A. Blomstermo, "The internationalization process of born globals: A network view," International Business Review, 12(6), 2003, pp. 739-753.

43. D. Sharma, and A. Majkgård, "Client following and client seeking strategies in the internationalization of service firms," Journal of Business-to-Business Marketing, 4(3), 1998, pp. 140.

44. J. Shaw, "Managing all your enterprise's risks," Risk Management, 52(9), 2005, pp. 22-30.

45. L. Simoneou, "Enterprise search: The foundation for risk management," Knowledge Management World Conference, 2006.

46. W. Stam, S. Arzlanian, and T. Elfring, "Social capital of entrepreneurs and small firm performance: A meta-analysis of contextual and methodological moderators," Journal of Business Venturing, 29, 2014, pp. 152-173.

47. P. D. Stephen, "Enterprise risk management," Journal of Risk Management of Korea, 12(1), 2001, pp. 1-24.

48. Z. Sulaiman, N. M. Noor, N. Singh, and P. Y. Suet, "Evaluating the effectiveness of digital storytelling with panoramic images to facilitate experience sharing," Computer Science, 4552(3), 2007, pp. 981-989.

49. K. Sutcliffe, and K. Weber, "The high cost of accurate knowledge," Harvard Business Review, 81(5), 2003, pp. 74 82.

50. W. L. Tan, F. Lam, and W. C. Lau, "An Empirical Study on 3G Network Capacity and Performance," 26th IEEE International Conference on Computer Communications, Joint Conference of the IEEE Computer and Communications Societies, 2007, pp. 1514-1522.

51. P. Tufano, "Managing risk in higher education," Forum Futures Symposium, 2011, pp. 54-58.

52. B. Warren, "What is missing from the RMIS designs? Why enterprise Risk Management is not working," Risk Management, 49(10), 2002, pp. 30-34.

53. K. Weick, Making Sense of the Organisation: The Impermanent Organization. New Jersey: John Wiley and Sons, 2012.

54. K. Wiig, Knowledge Management Foundations: Thinking About Thinking-How People and Organisations Create, Represent and Use Knowledge. Arlington: Schema Press Limited, 1993.

55. M. G. Zadeh, Risk management implementation in the Iranian construction industry from contractor's perspective. Master thesis, Johor: Universiti Teknologi Malaysia, 2010. 